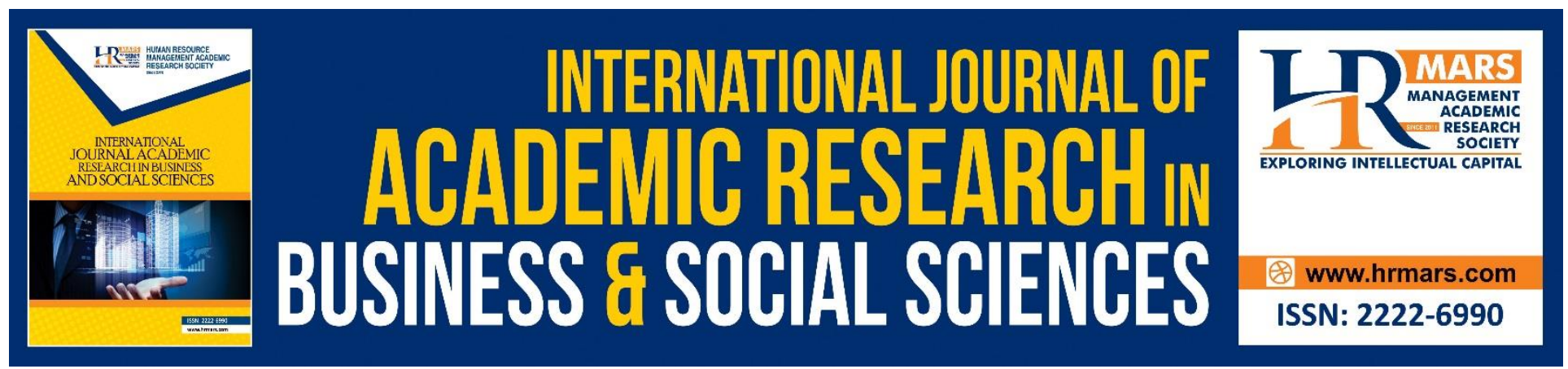

\title{
The Impact of Covid-19 Pandemic to Worship
}

Faisal Bin Husen Ismail, Arwansyah Kirin, Muhammad Masruri, Siti Marpuah

To Link this Article: http://dx.doi.org/10.6007/IJARBSS/v10-i11/8081 DOI:10.6007/IJARBSS/v10-i11/8081

Received: 09 September 2020, Revised: 01 October 2020, Accepted: 25 October 2020

Published Online: 12 November 2020

In-Text Citation: (Ismail, Kirin, Masruri, \& Marpuah, 2020)

To Cite this Article: Ismail, F. B. H., Kirin, A., Masruri, M., \& Marpuah, S. (2020). The Impact of Covid-19 Pandemic to Worship. International Journal of Academic Research in Business and Social Sciences. 10(11), 244-258.

\section{Copyright: (c) 2020 The Author(s)}

Published by Human Resource Management Academic Research Society (www.hrmars.com)

This article is published under the Creative Commons Attribution (CC BY 4.0) license. Anyone may reproduce, distribute, translate and create derivative works of this article (for both commercial and non-commercial purposes), subject to full attribution to the original publication and authors. The full terms of this license may be seen at: http://creativecommons.org/licences/by/4.0/legalcode

Vol. 10, No. 11, 2020, Pg. 244 - 258

Full Terms \& Conditions of access and use can be found at http://hrmars.com/index.php/pages/detail/publication-ethics 


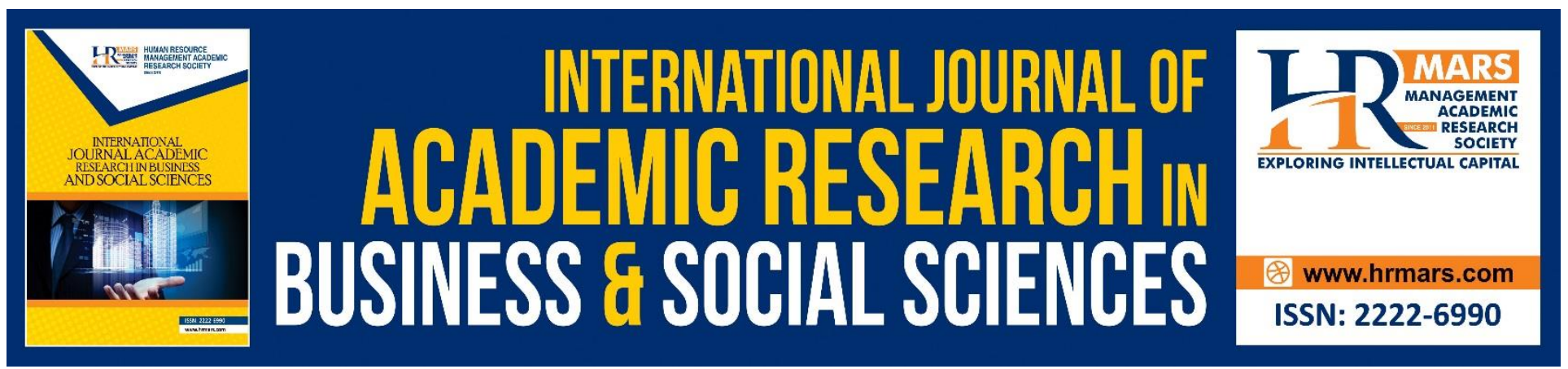

\title{
The Impact of Covid-19 Pandemic to Worship
}

\author{
Dr. Faisal Bin Husen Ismail \\ Universiti Tun Hussein Onn Malaysia, Centre for General Studies and Co-curricular, 86400 Parit Raja, \\ Batu Pahat, Johor, Malaysia \\ Email: faisalhu@uthm.edu.my
}

\section{Dr. Arwansyah Kirin}

Universiti Tun Hussein Onn Malaysia, Centre for General Studies and Co-curricular, 86400 Parit

Raja, Batu Pahat, Johor, Malaysia

\section{Dr. Muhammad Masruri}

Universiti Tun Hussein Onn Malaysia, Centre for General Studies and Co-curricular, 86400 Parit

Raja, Batu Pahat, Johor, Malaysia

\section{Dr. Siti Marpuah}

Universiti Tun Hussein Onn Malaysia, Centre for General Studies and Co-curricular, 86400 Parit Raja, Batu Pahat, Johor, Malaysia

\begin{abstract}
Spread of Covid-19 outbreaks so fast thus it is pandemic a major part of the world. The covid-19 outbreaks resulting in changes to the practice of worship and use of certain tools during the implementation of worship. Therefore, question what Covid-19 is affecting the law requires deep discussion and caution from various perspectives. This study aims to explore the perspectives of scholars and arguments used as well as highlighting the fundamental principles of Islam that should consider when assessing the permissible changes of the law due to the covid-19 outbreak. The method of this study is descriptive qualitative. The books of classical and contemporary scholars are the primary references to this study. Besides that, the journal articles, and national and international fatwa councils as the secondary references of this study. This study found, Temporary suspension of Friday prayers, Congregational Prayers the use of hand sanitizer for the purpose of epidemic control and medical accepted as a legal variable when it meets the prescribed conditions by the authority. Ethical guidelines need for infected persons to be a distance at home to prevent others from being infected. The principles of maqasid al-sharia for human well-being (sustainability), descent and reject the harm as well as preventing harm is take precedence from securing the benefits, it is among the principles of guidance in assessing the change in the Islamic law because of the covid-19 outbreak
\end{abstract}


INTERNATIONAL JOURNAL OF ACADEMIC RESEARCH IN BUSINESS AND SOCIAL SCIENCES Vol. 10, No. 11, 2020, E-ISSN: 2222-6990 ๑ 2020 HRMARS

from an Islamic perspective. This study proposes an in-depth study conducted to discuss and explore other changes in the Islamic law related to the covid-19 outbreak.

Keyword: Covid-19 outbreak, Pandemic, Worship, Fiqh, Muslim.

\section{Introduction}

The Corona virus appeared for the first time at Wuhan China (Huang et al., 2020; Shultz, Perlin, Saltzman, Espinel, \& Galea, 2020). The spread Covid-19 is so fast. Only in a few months, many people are infected with corona virus and have caused numerous deaths (Organization, 2020). The spread of this virus can occur through touch or speech (Fraire, Woda, Welsh, \& Kradin, 2014; Lee, Jobe, \& Mathis, 2020). The corona virus is said to be from a bat that attacks humans, which can lead to death after severe shortness of breath (Rezaei, 2020; Zhou et al., 2020).

Now after covid-19 it becomes a pandemic, has caused the concern among Muslims in conducting the worship activities in daily. This is because it conducts the worship of Muslims in congregational in public places such as mosques. Activities after-prayer such as shake hands are also affect caused worries infect by the virus when shaking hands between people who have infect with covid-19.

Worse yet, according to the observations, there were not few studies have conducting on the effects of the covid-19 outbreak on the Islamic law. Therefore, it is important to conduct this study conducting to explore the views of scholars about the subject above. The study urgent to conduct to clarify the position and procedure of worship during the covid-19 outbreak. This is because the number of deaths increased daily because of exist community gatherings in places including mosques.

We conducted this study to discuss of the legal issues that arise in relation to the Muslim worship practices during the covid-19 outbreak. The important this study is to study and analyze the views of scholars and the methods used on the practice of worship conducted during of the covid-19 outbreak. The analyzing to clarify the misunderstanding among the society can doing about worship during of the covid-19 outbreak.

\section{Literature Review}

The dynamics of the Islamic law carateristic shows the ability of Islamic law to face change the times. The response to the changing social environment of society is fast becoming a consequence of Islamic law as a rahmatan lil 'alamin (Ibn Rushd, n.d). Changes in the law are necessary because the norms arrange human life is aimed to control the behavior that people want (Friedman, 2011). While Dienes (1972) linked the change of laws will result in the regulatory and authority engagement that resulted in such changes as legislative and judicial. However, changing the law is not easy to do because change is possible to feel by all level of society. At the same time, the legal changes made by the legislature are not effective because the timing of the change in legal time needed to rule has changed (Grad, 1949). The changing of situation and social conditions of society is one of the variables to a law as verbalized by Max Weber believed that change exists to trigger better ideas and the society is in an organized and integrated system(Brubaker, 1984). Weber emphasized the transformation of society into three stages, namely the traditional law society, the charismatic society dominated by the charismatic legitimacy of the respected people, and the final stage is the rational society with the shape of rational-legal (Ali, 1998). While Durkheim (1964) argues that social change in society is also influenced by material that causes in a change the structure of society. As the population increases, 
the division of labor also influences change. As a result, the morals and behavior of the people has also changed. To handle the effects of competition in society, moral values are the most important factor to resolve the matter (Durkheim, 1964). However, these changes according to Jurgen Habernes, occur due to the behavior of modern society (Habermas, 1984). Changes in the law are also explicitly stated in the Quranic revelations regarding the law from being difficult to easy or enabling something that was originally illegal after a variable factor such as a wish to sustain life (Kamil, 1999). This shows that the law don't miss from changes and is a legal habit aligns with the change of human condition. The changes studied in this study consist of the change in environmental conditions in the context of this study as the effect of the covid-19 pandemic as it is one of the variables in law.

\section{Research Methodology}

This study uses descriptive qualitative methods (Kirk, Miller, \& Miller, 1986). The library method is a suitable design for the design of this study. The primary sources of this study are references to the books of classical and contemporary scholars. In addition, the journal, articles, and fatwas issued by the authority institutions are the secondary sources to this research. This review also referred to maqasid al-shariah as a comparative research to refine the analysis.

\section{Research Problem}

The problem to this research is has not been studies to clarify the view of worship during the covid19 outbreak. There are even those who question the validity of uncommon practices from the rule of law in ordinary circumstances. E.g. legal practices of mask when applying worship or the use of hand sanitizer without rinsing after practice. These questions need to be careful review as the doubt of its application can cause to invalidity of worship. This is important to the public in the immediate period.

\section{Findings and Discussions}

We discuss the following some of the issues related to the legal changes caused by the covid-19 pandemic.

\section{Use of Face Mask during Worship During Performing Hajj and Umrah}

Wearing of mask for mouth and nose while performing umrah or pilgrimage is a matter of precaution. According to Al-Zuhayli (1997), female ordered to cover all over the body while performing prayers and pilgrimage except the faces. This is because the female ihram is on the face. The men require to open their faces while performing pilgrimage and umrah.

Therefore prohibited to men and woman to covering the whole or part of the face while pilgrimage with clothes (something) stitched clothes. This is just as prohibition to wear a stitched dressed all over the body (Al-Buhuti, 1997). It bases this prohibition on the words of the Prophet Muhammad pbuh when answering a question from a man who asked about the clothes used during the pilgrimage. He informed that prohibited clothing was a dressed shirt, head cover (sorban), pants, khauf, but when there is no slipper, can wear an abrupt cut under feet. The Prophet Muhammad (Pbuh) prohibits from wearing all kinds of clothing that is dyed in za' faran (varnish) and turmeric (AlBukhari, n.d; Muslim, 1992) 
INTERNATIONAL JOURNAL OF ACADEMIC RESEARCH IN BUSINESS AND SOCIAL SCIENCES Vol. 10, No. 11, 2020, E-ISSN: 2222-6990 @ 2020 HRMARS

The Hanafiah and Malikiyya schools are of the view that it is illegal to cover the face for members of the pilgrims in ihram. They say his arguments based on hadith of the Prophet Muhammad pbuh as Ibn Abbas reported that he prohibits for Muslims to cover face and head (Muslim, 1992). Even the person who covers his face during the ihram must pay fidyah. Sheikh AlDardir (1980) said: "It is forbidden for men to cover all his face or partly or cover head. Includes whatever said to be closed e.g. closing with clay, so it is especially if closing with something else like pants. Thus, closing the face and head is different in the law than closing the other parts of body. Therefore, it is forbidden to cover your face and head with anything that whatever counts off (AlDardir, 1980). While Al-Marghinani (1990) also stated it is forbidden to cover the face of the person of the pilgrimage. This prohibition is under said prophet Muhammad pbuh, who prohibits the covering of faces and heads of the pilgrimage, as it will raise them on the day of judgment under the circumstances of the pilgrimage. A woman who pilgrimage to not cover her face even if the face cause of the slanderer of the woman. Therefore, if it confines to men, then it is more important to ban face during pilgrimage.

Instead of, Shafi i and Hambali schools allow closing the face for the pilgrimage and not having to pay fidyah. Imam Asy-Syairazi (1995) declared that nothing prohibition to a pilgrimage to cover his face. He declared that prohibit of the Prophet in hadith on the pilgrimage was to cover head only and not prohibit to cover of the face. While al-Nawawi (1990) declared the views of the shafi i school and majority scholars accepted for men who are pilgrimage to cover their faces and not be pay fidyah.

The Shafi i school argues with the authentic hadith narrated by al-Shafi i from Sufyan bin Uyainah from Abdul Rahman bin al-Qasim from his father whose sahabah such as Uthman bin Affan and Zaid bin Thabit and Marwan bin al-Hakam covered their faces while in pilgrimage (Al-Baihaqi, 1993).

Based on the above discussion, there is a difference in the sect's view about the law of wearing face masks during performing pilgrimage and umrah. This difference is for understand of the respective sects' denominations on a referenced hadith. Although it looks different, it can combine the two opinions. If there is no need and reason to cover the face while performing the worship, then not need to cover the face. But from the point of paying fidyah, then it returns to their respective sect. Al-Ruhaibani (1961) said that a Muslim man does not have to pay fidyah if it covers his face because it does not violate any practice of circumcision covering the body or violates the prohibition of laying hands on the head. So, they consider face masks like putting honey or its kind because of anxiety hit the dust on the skin. Thus, there is no need pay fidyah according to the narration of the hadith narrated from Ibn Umar who saw the Prophet's wiping the sweat on his skin.

Therefore, if there is it allows a need to wear a face mask during performing hajj or umrah worship for health. This is because it gives the need for health care priority in religion. Likewise, everyone is not immune system to force against the environment. There are members of the pilgrims do not have the strong immune body endurance to viruses or germs. Thus, prohibition of wearing masks if not need. But for those who wish for health reasons, for example, they allow it. This is proper with the maqasid al-Shariah to preserve life. Using face masks for the reason requirements is the same between men and women and is not pay fidyah. Ibn Qudamah (1979) said that prohibition for women to wear face masks or like that they it intends them cover the face. Therefore, the mouth and nose masks accepted for health certified by a medical professional such as a doctor or herbalist and not just on suspicions. 
INTERNATIONAL JOURNAL OF ACADEMIC RESEARCH IN BUSINESS AND SOCIAL SCIENCES Vol. 10, No. 11, 2020, E-ISSN: 2222-6990 @ 2020 HRMARS

\section{Prayer}

Cover it prohibits the mouth and nose during praying. This is because the nose is one member of the face that must touching with a prostrate place. We found the prohibition for cover the mouth during prayers in the hadith of the Prophet Pbuh narrated from Abu Hurairah that he should not cover the mouth during performing prayers (Ibnu Majah, 2009). Al-Syarbini (1415 H) explaining that the prohibition on hadith shows only makruh (disapproved) in the fiqh. He said, makruh to worshipers wearing the clothes with pictures, prayers cover his mouth and (makruh) when a woman prays by wearing niqab (cover face) (Al-Syarbini, $1415 \mathrm{H}$ ) (1:24).

It bases this on the Arabic habits using the end of the cloth rida ' (al-Talaththum) cover their mouth and nose during performing preyers (Al-Khattabi, 1932). Ibn al-Munzir (2010) said that majority scholars decided makruh to cover cover the mouth and nose during performing prayers. It is a judgement Ibn Umar, Abu Hurairah, Atha', Ibnu al-Musayyib, al-Nakha`i, Salim bin Abdillah, alSya'bi, Hammad bin Abi Sulaiman, al-Auza'i, Malik, Ahmad and Ishaq (Ibn al-Munzir, 2010) (3: 451). Prominent scholars such as Ibnu Abi Syaibah based on hadith narrated by Nafi (Ibn Abi Syaybah, 2004) (no. 7306), Said bin Musayib and Ikrimah (Ibn Abi Syaybah, 2004) (No. 7307), Thawus (Ibn Abi Syaybah, 2004) (No. 7308) and Hasan al-Bashri (Ibn Abi Syaybah, 2004) (No. 7310) decided makruh to cover the mouth and nose during performing prayers. Imam al-Nawawi (1990) says, who thinks makruh of the acts to covering the mouth and nose with the hand or cloth during performing prayers.

The prohibition to cover the mouth and nose also because the practice is like Majusi's religious practice as proposed by Al-Syawkani (1996). So cover mouth while prayers can prevent the perfection reading of the Quran and prevent perfect the faces prayers from being prostrated (al-Qari, 2002).

However, makruh of the act can change when there are variables requirements such as medicine. Therefore, cover the mouth because of sneezing in prayer for example, allowed for the reason of limiting saliva and sound during sneezing. Cover the mouth by hand also encourage occur a virus corcern with attach to the palm of the hand and will transmigrate to others while shaking hands. It bases this on the hadith narrated from Abu Sa'id al-Khudri that he commanded to cover the mouth while he was vomiting during performing prayers or outside prayer (Muslim, 1992).

Based on above discussion, it prohibits cover the mouth and nose during performing prayers. However, there is a condition that requires to cover the mouth or nose or both during performing prayers, accept for certain reasons. al-Nawawi (1990) (3:179) said that law of makruh cover the mouth only or cover the mouth and nose with hand or other. However, accept to cover with hand while sneezing on the person performing prayers. Thus, cover the mouth with hand is more fulfilling to sunnah of the prophet Muhammad Pbuh in this matter as told in hadith narrated by Abu Sa id alKhudri. An-Nawawi also explained the same law applies to women and khuntha (al-Nawawi, 1990).

Even the law wears a face mask when prayers changes to circumcision when not cover the mouth or nose can cause the virus to transmigrate during sneezing and cause harm to members of the congregation. For examples of sneezing are held with palm of the hand of a person infected with the corona virus, the virus will stick on the hands. If the congregation shakes hands with another, then the spread of the viruses will occur and cause in harm to others. Thus, wearing the mouth and nose cover is a necessity and similarity served by the sunnah at the time of the covid-19 outbreak for personal and public health purposes. This is also because someone would use his hand to eat, to hold and shake hands with others. But wearing face masks during worship is based on recommendations from authorities such as doctors or the health ministry. Sheikh Ibn Uthaimin said that they allow it for the prayers to close the mouth with hand. But if they do it without cause then it considers to be 
INTERNATIONAL JOURNAL OF ACADEMIC RESEARCH IN BUSINESS AND SOCIAL SCIENCES Vol. 10, No. 11, 2020, E-ISSN: 2222-6990 @ 2020 HRMARS

makruh. Likewise, if there is a smell bad around it, then cover the nose with hand allowed for the sake of necessity. The worshiper has a cold to control it and treat it, thus they allowed to cover their mouth and nose with a face mask (Al-Uthaimin, $1422 \mathrm{H}$ ).

Therefore, not wearing a mask when performing the congregational prayer can transmigrate disease virus to others is consider makruh. It can even be a sin if they fear it could spread viruses to other after advice by the authorities. This is a priority for people with Covid-19 symptoms such as cough, cold nor a fever. This is to further control the spread of Covid-19 outbreak. Changes law makruh (offensive act) to mubah (neutral) even mustahabb (recommended) where there is a need and compatible with the method qawa id fiqhiyyah:

$$
\text { الكراهة تندفع مع وجود الحاجة }
$$

Makruh acts eliminated when ther is a need.

Under above method, Ibnu Abdil Bar said as Ibn Qudamah certified him by pointed out in the book of al-Mughni that the scholars agreed that women must open their faces during prayers and ihram. This is because cover the face will prevent the person praying from the forehead and nose to the place prostrate as the Prophet prohibits men than to do that. The acts not disapproved (makruh) if need for women to cover their faces such as non-mahram men. The men require to cover their mouths and nose if there is a need to do that (Ibn Qudamah, 1979) (1:432).

\section{Use of Hand Sanitizer}

Alcohol is the fundamental ingredient used in disinfecting fluids (hand sanitizer). Using alcohol related materials is a matter disputed among scholars over its halal (legality). In addition, its use before prayer, then do not wash hands again use pure water (mutlaq).

According to Islam cares about cleanliness and personal hygiene, clothes and place in all situations when performing prayers. Even Islam prohibits the use of illegal sources to perform worship. For example, the use of ablution water from stolen goods or using a cloth that steal to perform prayers. The jurists assume valid the prayer but sin for stealing water that is haram acts (forbidden) (Al-Wezarat \& Al-Kuwaytiyyah, 2007). Using liquid on the body consider in Islam whether it is halal (permissible) or forbidden. They often use the use of alcohol in hand sanitizer fluids is often in hospitals and homes to blame germs. Therefore, the question arises as to permissible or forbidden of alcohol use in hand sanitizer or other uses.

Be related this, some scholars argue for alcohol are najis (it cannot purify things). However, they still allow to use of alcohol mixed with perfume just for sake of it. While others argue that alcohol are impure things. This is as presented by Al-Jaziri (2003) (1:15) that one thing being forgiven is the use of fluids mixed with medicines or fragrances to make a maslahah (public interest) effect on its. But it bases forgiveness on giving maslahah only.

Al-Zuhayli (1997) (7:210) said that pure alcohol or mixed with something else like perfume is pure. Use of impure sentences (rijsun) In the Quran, related to alcohol does not mean dirty or impure, but means the act of sin. It also bases this is also on the principle that everything is pure. they consider pure alcohol or mixed with water. They base this view on the views of majority scholars who emphasize (choose) explain "rijsun" from the angle of maknawi than the literal act (harfiah) is devil's act and bad (Al-Zuhayli, 1997). Sheikh al-Zuhaili allows for use of alcohol for medical such as cleaning wounds, disinfects skin, mix in medicines and to remove germs and viruses from the palm or use as a mixture of perfume. This is with the view issued by al-Azhar's fatwa (religious opinion) as quoted by Ahmad As-Syarbashi that alcohol is not contaminate as impure (Hadzami, 1986). 
INTERNATIONAL JOURNAL OF ACADEMIC RESEARCH IN BUSINESS AND SOCIAL SCIENCES Vol. 10, No. 11, 2020, E-ISSN: 2222-6990 @ 2020 HRMARS

Based on the discussion above, debates scholars and the arguments presented it we can deduce it that alcohol use accept based on a stronger justified. However, it is using limit to necessity. Therefore, using alcohol in hand sanitizer accept and does not affect the validity of the prayers. Using hand sanitizer before prayer without washing does not cause the prayer to deteriorate due to its use as far as need and jihah munfakkah (separate angles) from the prayer. This also something excuses for the scholarly view alcohol is pure. This is because a lot of harm on alcohol which is intoxicating and prohibited by Islamic law and the grave sin of those who drink it and is subject to hudud. However, it has some benefits such as cleaning wounds, germs, or viruses. This is meant in sura alBaqarah verse 129 as it present Al-Zuhayli (1997).

\section{Related to Mosques}

\section{Use of Donations for the Disinfection of Mosque Area}

The mosque is the exclusive and sacred place for Muslims around the world. They perform various rituals of worship such as congregation prayers, Friday prayers and science lectures, Islamic carnival, and Islamic forum. However, not limit activities in the mosque to the above rituals. Help to the poor and other social activities can also conduct from mosques. Even in the time of the Prophet Muhammad (peace be upon him), it conducted the administration of the state of Medina and military from the mosque. All these spiritual and social activities are suitable with the role of mosques as a place to develop Islamic propagations.

To conduct the activities above, they need funds to implement. The fund's donation from mosques are among the major sources of implement planned activities. Manage the mosque is a key part of the responsibility of each activity and all aspects of the program's effectiveness. These include managing the mosque to help the smooth activities for the benefit of the community and ummah. The prosperous of the mosque is an order from Allah to his servants as contained in the Quranic sura al-Tawbah verse 18 .

Mosque and surau donation funds are a public trust for committee members to best manage their affairs. This is in line with direction Allah Almighty in the Quranic surah Al-Nisa`verse 58 which commands that the trust give to members who can carry it out among the people. This is with direction Allah Subhanahu Wataala in the Quranic sura Al-Nisa verse 58 which ordered that the trust give to members who could implement among the people. Hence, to achieve this goal, the committee members must use the power given to them using a reasonable amount of money to administer the mosque. This is because they must balance the use between the physical development of the mosque and the spiritual members of the congregation and committee members.

The question is, can a general and be specific donation to use by mosque committee members for the disinfectant the corona virus in a mosque area? Or is it necessary to create a special fund for that purpose? This is because mosque fund management procedures often to pose a polemic among the committee members and community. Where will the funds have used or donated? They can use it for the public interest (maslahah) of community or is it only for mosque purposes. When a special fund helps families affected by covid-19, can they use it for other individuals or other needs such as helping a front-line healthcare treating covid-19 patients?

To answer the issue, should explain meaning of tabarru '(donation). Scholars define tabarru as an attempt to impart wealth or help by the mukallaf to the present or the future expecting no reward intending to do good welfare because of Allah. While of its kind include waqf, wills, hibah, donations and so on (Al-Wezarat \& Al-Kuwaytiyyah, 2007) (10:65). Instruction of the tabarru 'is 
INTERNATIONAL JOURNAL OF ACADEMIC RESEARCH IN BUSINESS AND SOCIAL SCIENCES Vol. 10, No. 11, 2020, E-ISSN: 2222-6990 @ 2020 HRMARS

similarly with the verse in sura Al-Maidah verse 2 which instruction to Muslims and others to helping each other out in the good that benefits to the human beings by providing material and financial help. Hence, donations, and wakaf to the mosque including in the tabarru 'type.

Among contributors organize their donations for a specific purpose. The committee members should do so based on plan the contributors. An example, contributor's intention to supply educational help to community who studies abroad. Therefore, the donation must be to the purpose only and have not apply for other. To comment on the matter, Sheikh Zakaria al-Anshari (2003) (2:479) states: If someone gives him some dirhams and says: "Buy turban for yourself with this money or bring turban to the bathing area", or (speech) of such, then the person must do that to celebrate the purpose of the individual contributing the money. Then he said again, if a person donates for the purpose of having the money man to cover his head with a turban and requires the person to cleanse his tangled hair, then the person should do so when receiving the donation. However, if the donates not accompanied by any intention, it is up to the recipient to use it customarily and allowed to use it according to his needs (Al-Anshari, 2003) (2:480).

Based on the above explanation, when it compare to mosque fund management, if the donates does not dedicate his or her contribution to the purpose of the donation to the poor, widow or others, then it is possible for members committee of the mosque and surau to donate the donations to asnaf or other uses that may consider appropriate for the benefit of the mosque or to help them. If the donates wishes to donate or donate to the general fund in mosques and surau, they may use this donation for mosque activities or to aid those in need such as B40.

To reinforce this view, Al-Ghazali thinks as cited by al-Nawawi (1990) (9:351) in al-Majmu's book relating to the use of illegal property for the benefit of the public: When a person is with him an illegal property, then he wants to repent and get away from it, then if the illegal property has a specific owner, it must submit to its owner or its representative. If the person (property owner) has died, then he must give it over to his heirs. And if the property is own by someone they don't know, then the money should go to the public interest (maslahah) such as construe bridges, mosques and the need to build roads in Mecca and so on where Muslims enjoy it.

From the above view, if the money could not determine they could use its owner for the public interest of Muslims, they put then more important the halal money that into the mosque fund was put into the mosque fund was even more valuable for the benefit of the public. The situation covid19 outbreak has caused B40s to help because of the Movement Control Order (MCO) for the purpose of controlling the spread of the corona virus. It forces many family heads to work, traders could not to open a sales booth.

Besides necessary using the fund of mosque as above, the donation can also use for covid-19 virus eradication work by spraying certain materials on the floor and carpet of mosques. This is because it contains a maslahah which is the safety care the community than infected the corona virus.

Hence, the usage of the money may use for maslahah of Muslims and community of the mosque. However, priority should give to the activities of the mosque, supported, and help the community around the mosque, the asnaf (categories) and the B40 group. Therefore, so good for the committee in managing donations, to put special funds to easy collect and distribute donations for those specific purposes. It recommends for the public to donate to mosque funds for the benefit of the Muslims. 
INTERNATIONAL JOURNAL OF ACADEMIC RESEARCH IN BUSINESS AND SOCIAL SCIENCES Vol. 10, No. 11, 2020, E-ISSN: 2222-6990 @ 2020 HRMARS

Members of the mosque committe must discerning in spending the funds. This coincides with one of the methodological of Islamic jurisprudence:

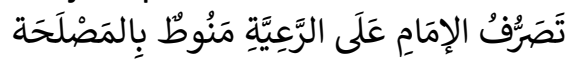

The management or response of negotiations on the people should be

tightly to public interest (maslahah).

The leader in this context is a member of mosque committe need to spend the donations that bring benefits and public interest to mosques and community under their responsibility (Al-Suyuthi, 1979) (1:122).

\section{The Obligatory Friday Payer and Congregational Prayer}

It has been obligatory to the Muslims who are performing the Friday prayers in congregation. The scholars agree on the obligatory of Friday prayers on every Muslims of all responsible (mukallaf) (AlKhin, 2003) (1:200-201). They base this on the command of Allah SWT in sura al-Jumuah verse 9 (AlBaydhawi, 2003). Likewise, the superiority of praying congregational at mosques has 27 times more than alone prayer (Muslim, 1992). In normal circumstances, they classify those who leave Friday prayers as sinners (Al-Khin, 2003) (1:198). According to the hadith of Muhamamd pbuh which state that: "The Friday prayer is the obligatory duty of all Muslim in the congregation except for four categories: slave, female, child or sick" (Daud, 1981).

However, exist certain circumstances can cause to changes to the obligatory Friday prayers and congregation prayer practices. As told in hadith above, that sickness is one cause for fall of Friday's duty. To safety guarantee is one thing that can consider as an illness of obligatory Friday's prayer. It is similarly the duty of pilgrimage to fall because no guarantee of travel or destination of hajj (Mecca). However, the reasons for the change must acknowledge (muktabarah) that the authorities confirm them. Method of Islamic jurisprudence provides "al-hukmu yaduru ma`a al-Illah wujudan wa 'adaman" which is a law following the existence or unavailability of "illah (causes). The Friday prayers may fall on 'illah reasonable.

Hence, the covid-19 outbreak can categorize as part of the lack of safety from infected viruses that could abolish of Friday prayer and congregation prayer. However, there are scholar's views that the duty of Friday's don 't miss it for the covid-19 outbreak. They think Covid-19 cannot be an excuse to drop something that obligatory from Allah SWT.

But according to majority of the jurist, including the national fatwa councils and international fatwa councils are views that the obligatory of Friday's prayer as suspended because of the Covid-19 outbreak. The Fatwa Shar'i Council United Arab Emirates (UAE) stated: "Forbidden (haram) for anyone infected or suspected of the corona virus to be in a public palace or go to a mosque to perform Friday prayers, congregations or Eid prayers. They also require it is also to take all precautions against covid-19". While the fatwa from The Kurdistan regional fatwa council said: "it cannot cancel the Friday prayers, except in places where the virus has become a pandemic". The same fatwa present by Fatwa Committee of the Assembly of Muslim Jurists of America (AMJA).

Prohibition of attending to a place infected with covid-19 outbreaks based on Quranic evidence. Allah SWT says in surah al-Hajj verse 78 which means: "... He has chosen you and has not placed upon you in the religion any difficulty...". The easy spread of covid-19 in public gatherings including Friday prayers and congregation prayers includes exposure themselves to viruses. We can say this to be a difficulty in fulfilling religious obligations. This is one type of rukhsah (mildness) and 
INTERNATIONAL JOURNAL OF ACADEMIC RESEARCH IN BUSINESS AND SOCIAL SCIENCES Vol. 10, No. 11, 2020, E-ISSN: 2222-6990 @ 2020 HRMARS

abolish accredited of the Shari'ah. Even the order to save from dangers or to plunge into misery is proper with the command of Allah SWT in sura al-Nisa' verse 29 and surah al-Baqarah verse 195.

Addition, according to the hadith spoke about prevent an action going to the tha epidemic. The Prophet Muhammad (PBUH) forbade entry to the tha'un epidemic and prohibits the people inside to leave it (Al-Bukhari, n.d; Muslim, 1992). The same is in hadith narrated Ibnu Majah (2009) that the Prophet Muhammad pbuh Prohibit harmful to others or harm others. Based on the two hadiths above, the Prophet Muhamamd pbuh explained think people outside the infectious disease area and prohibited those in the area to exit to another place. Thus, the Prophet's command not to harm others. Both hadiths were under the covid-19 outbreak for the temporary suspension of Friday prayers and congregation prayers.

The Prophet Muhammad pbuh also reminded in the hadith regarding to prohibit sick people visit to the healthy: "People who are sick should do not visit to a healthy person (Al-Bukhari, n.d). This hadith shows the width of religion and rukhsah that religion gives to the sick. In the covid-19 outbreak, people are unaware that they have infected him with viruses except after inspected examined by the doctor. Hence, to prevent the public from infect with viruses, the suspension temporary of Friday's prayer include in the matter of keeping the sick visit to healthy people. However, the opportunity to perform congregational prayers and to get the reward of congregational still exists by performing congregational prayers in their homes. Even the one who have a health did not allow himself to attend on Friday prayer and the congregation got a reward of performing he Prophet's sunnah to save his life from being infected or infecting viruses to others.

In addition, the hadith narrate by Daud (1981) (hadith no. 551) and Al-Daruquthni (2004) $(1: 420)$ the Prophet Muhammad pbuh says: "Whoever hears the chanting of the azan then it is not the health that prevents him from following it (congregation prayer) ". The companions asked: "What do you mean barriers?" The Messenger of Allah (may peace be upon him) said: "Fear or illness." The Covid-19 is a realistic anxiety not a thought, that allow leave Friday prayers and congregational prayers. Al-Zuhayli (2008) (1:497) stated that every illness is at the same as a caused of the pain, they consider it to be abolish compare with the pain it postulated. Therefore, it is not obligatory the Friday's prayer for the person to anxiety of themselves or their wealth".

The Prophet Muhammad pbuh warning to avoid from leprosy patient like a rescuing from a lion (Al-Bukhari, n.d). Avoid the disease leprosy is an attempt to prevent leprosy, while avoiding it is an effort only.

The temporary suspension of Friday prayers and congregational prayers based on the government's ijtihad (ulil amri) on expert advice (ministry of health) for maslahah (life-sustaining) as a recognized act of shariah. This is similarly with the Islamic legal maxims: "The management or response of negotiations on the people should be to public interest (maslahah)". The temporary suspension of Friday prayers and congregation prayers also proper with the Islamic legal maxims (qawaid fihiyyah) method of Islamic jurisprudence, refusing the damage (mafsadah) rather than benefiting. Other the Islamic legal maxims supply warding off detriments takes priority over get benefits". Both methods show that warding off detriments takes priority (protection of life) over get benefits (assembling a duty of Friday prayer) and to reject the general harm is the spread of covid-19 outbreaks caused to death. This is also to gain the common benefit of saving human life which is one of the aim of Islamic law (maqasid al-Shariah) (Al-Raysuni, 2005).

Whereas from the sources of ijma ' (consensus), the jurists agreed that misery must eliminate. They agreed to make it a method that covering everything. Therefore, this method includes distance 
INTERNATIONAL JOURNAL OF ACADEMIC RESEARCH IN BUSINESS AND SOCIAL SCIENCES Vol. 10, No. 11, 2020, E-ISSN: 2222-6990 @ 2020 HRMARS

own self from the person affected the covid-19 to save lives from destruction and to save themselves from harm.

The next evidence for Friday's suspension and congregation prayer is qias (correlated). The Prophet forbade people with smells that could interfere with others entering the mosque. Imam Muslim (1992) recounts the hadith that Umar Bin Khattab r.a preaching on Friday: "Then you people eat two kinds of foods I think are bad as onion and garlic. I saw the Prophet pbuh when he found the smell of onion and garlic in a person, he orders him exit to Baqi', anybody wants to eat, should cook first. Based on hadith above, could connect to the reality of a covid-19 outbreak. If the Prophet ordered his companion exit from the mosque because of the smell of onions, then covid-19 is more harmful to other people's lives. Then is more proper to be the distance from the mosque.

Sheikh Ibn 'Abd Al-Bar (1387 H) (6:422) stated that when a person isolate from the mosque because it hurting another congregation with the smell of onions. Then compared, all the things that cause a disturbance among worshipers such as bad smell, dangerous diseases such as leprosy or something like that, then it is possible that the person with these characteristics isolated from the mosque, as long as the existence causes (bad smell or like it). When recover, they can return to the mosque (Ibn 'Abd Al-Bar, $1387 \mathrm{H}$ ).

The Prophet's instructions for dealing with lepers. The Prophet Muhammad pbuh had forbidden people with lepers' disease to find the Prophet Muhammad pbuh in Medina for baiah (an agreement to give obedience). The Prophet sent messengers to the borders of Medina and informed him that the Prophet Muhammad had accepted his obedience and ask to return to his country. According to the sirah, for those affected with covid-19, they must isolated themselves at home and do not attend the mosque. Likewise, for a healthy person to avoid the places or people infected with covid-19 as Umar Bin Khattab once forbade his companions to entering the state of Sham when the tha un outbreak occurred.

In addition, for temporary, practices shake hands after prayers in the mosques should postpone reducing the interaction between the worshipers if it is anxiety to spread the virus. A member of the congregation who have symptoms of fever, cough, flu to not attend the mosque until its health from affect Covid-19. Likewise, the preacher of Friday to shorten the sermon to reduce human assembly until covid-19 can control. The same is to the public to perform ritual ablutions in their homes to reduce contact with people in both the toilet. Even the Prophet Muhammad informed that a man who was ablutions from his house forgive reward for every step to the mosque was elevate status (Muslim, 1992) (No. hadith 666).

However, using apply of this law depends on the current situation state at any place. This means, if a place does not have infected corona virus, then the obligatory of Friday prayers will not fall. But when the health ministry as the authority informed the area it affect and they confirmed many individuals positive covid-19, then the instructions is applicable apply to suspending Friday prayers and congregational prayer in mosques. Requirements for Friday prayer suspension and the congregation prayer should majority of the jurists (consensus) according to the Prophet s.a.w: my ummah (Muslims) will not agree on the embezzlement (Al-Tirmizi, 2008) (no. hadith 2167). They base the law on something on probability. Thus, be aware of the reality that is happening and not before it happens. When there is an event, scholars assemble to analyze the dangers posed by the virus and using its spread and how to deal with it. if any of these conditions exist, then the duties of Friday prayer replace by four rak'a prayers Dhuhr performed which individually or congregational. 
INTERNATIONAL JOURNAL OF ACADEMIC RESEARCH IN BUSINESS AND SOCIAL SCIENCES Vol. 10, No. 11, 2020, E-ISSN: 2222-6990 @ 2020 HRMARS

\section{Conclusion}

Based on the above discussion, this study found that the covid-19 outbreak gave changes to the Muslim worship practice. These changes include temporary suspension of Friday prayers and congregation prayers, fall the duty Friday prayers, enabling the usage a face mask during worship whether during the pilgrimage, umrah or prayer or even after prayer using hand sanitizer. The covid19 pandemic is one variable in the Islamic law.

The study also found that they must base the change on powerful reasons and not on speculative basis. Meanwhile, the opinions of the jurists may differ in the reasoning due to the way to analyze the arguments and the current situation. This is to explain that reasoning (ijtihad) in a place is not accept in another place until the situation occur. This enhance the dimension of the efforts to respect and enhance the status and role of scholars in applying and integrating of religious knowledge with waqi (current state). In addition, the sources of Islamic law such as the Qur'an, hadiths, ijma' (consensus) and qias (compared) are always relevant to the current state of human beings.

Then, this research is of the judge that violent viruses such as corona virus requires instructions from Muslim regions. Implementation of protocols based on the doctrines of sharia law, Islamic jurisprudence and maqasid Shariah. As an explanation, this research suggests a mix of decision-making of implementing ritual based on the basics: the main Shariah principles, qawaid fiqhiyyah, maqasid al-Syariah and local 'urf. Meaningful contributions from the early investigation, inspection of the adaptability of Shariah law; second, explore of criticism of the communities who use mosque fund money for the help of the congregation and the preventive of mosques and suraus; Three, practical and critical of Islamic countries for life-changing economic life whose borders are yet open despite the epidemic of Covid-19 epidemics; fourth, study of government candidates on public health; and begin implementing worship without distance SOP set by the authority for customs of the outbreak of deadly epidemics.

This study recommends new research on other laws related to covid-19 disease such as the practice of performing prayer for medical professionals during treating covid-19 patients. By doing these studies, will open the capabilities of Islamic jurisprudence in implementing religion and serving to humans.

\section{Acknowledgments}

This research was funded by the Research Fund E15501, Research Management Centre, University Tun Hussein Onn Malaysia.

\section{References}

Al-Baihaqi, I. (1993). Al-Sunan al-Shaghir (Vol. 7). Beirut: Dar al-Fikr.

Al-Baydhawi, A. S. A. (2003). Anwar Attanzeel wa AsrareAtta'weel, jld. 2. Beirut: : Dar al-Kutub al'Ilmiyyah.

Al-Buhuti, M. B. Y. S. A.-D. (1997). Kashaf Al-Qina (Vol. 2). Beirut: Dar Al-Kutub Al-Ilmiyyah. Al-Bukhari. (n.d). Sahih al-Bukhari. Beirut: Dar al-Fikr.

Al-Dardir, A. (1980). Al-Syarh al-Kabir 'Ala Mukhtasar Khalil. In. Mesir: Dar Ihya'al-Kutub al-`Arabiyyah. Al-Daruquthni, A. B. U. (2004). Sunan al-Daruquthni. Beirut: : Muassasah al-Risalah.

Al-Jaziri, A. (2003). al-Fiqh 'ala al-Mazahib al-Arba'ah. Beirut: Dar al-Kutub al-'Ilmiah.

Al-Khattabi, S. (1932). Ma'alim As-sunan. Beirut: Al-Maktabah Al-IImiyah.

Al-Khin, M. (2003). al-Fiqh al-Manhaji 'ala Madhhab al-Imam al-Shafi 'i, j. 1. Damshiq Dar al-Qalam. Al-Marghinani, B. (1990). al-Hidaya. Beirut: Dar Al-Arqam, 2, 142. 
INTERNATIONAL JOURNAL OF ACADEMIC RESEARCH IN BUSINESS AND SOCIAL SCIENCES

Vol. 10, No. 11, 2020, E-ISSN: 2222-6990 @ 2020 HRMARS

al-Nawawi. (1990). Al-Majmu'Sharh al-muhadhdhab (Vol. 7). Beirut: Dar al-fikr.

al-Qari, A. b. S. A. N. (2002). Mirqat al-Mafatị̆ Sharḥ Mishkat al-Mașabiḥ. Beirut: Dar al-Fikr, 2: 636.

Al-Raysuni, A. (2005). Imam Al-Shatibi's Theory of the Higher Objectives and Intents of Islamic Law. Imam Al-Shatibi's Theory of the Higher Objectives and Intents of Islamic Law.

Al-Ruhaibani, M. A.-S. (1961). Matalib Ula al-Nahy fi Syarh Ghayah al-Muntaha wa Tajrid al-Zawaid al-Ghayah wa al-Syarh. Beirut: al-Maktabah al-Islami.

Al-Suyuthi, J. ( 1979). Al-Itqān fi 'Ulūm al-Qur'ān. Beirut: Dar al-Fikr.

Al-Syarbini, A.-K., Muhammad. (1415 H). al-Iqna fi Hilli Alfadh Abi Syuja'. Beirut: Dar al-Fikr.

Al-Syawkani, M. B. A. (1996). Nayl al-Awtar min Ahadith Sayyid al-Akhyar Sayrh Muntaqa al-Akhbar, (Vol. 4). Beirut: Dar al-Khayr.

Al-Tirmizi, A. I. (2008). Sunan al-Tirmizi. Beirut: Dar al-Kutub al-'Ilmiyah.

Al-Uthaimin, M. B. S. (1422 H). Al-Syarh al-Mumti 'ala Zad al-Mustaqni' (Vol. 3). Riyad: Dar Ibn alJauzi.

Al-Wezarat, \& Al-Kuwaytiyyah, A. (2007). Al-Mausu'ah Al-Fiqhiyyah Al-Kuwaitiyyah. Kuwait: Dar AlSalasil.

Al-Zuhayli, W. (1997). al-Fiqh al-Islami wa-Adillatuh: Dar al-Fikr.

Al-Zuhayli, W. (2008). Al-Mu'tamad alFiqh al-Syafi'i. Dimasyq: Dar al-Qalam.

Ali, A. (1998). Menjelajahi Kajian Empiris Terhadap Hukum. Jakarta: Yarsif Watampone.

Asy-Syairazi, A. I. I. (1995). Al-Muhadzab fi Fiqh Al Imam Asy Syafi'i (Vol. 7). Beirut: Dar Al-Kitab Al Ilmiyah.

Brubaker, R. (1984). The Limits of Rationality: An Essay on the Social and Moral Thought of Max Weber. London: Allen \& Unwin.

Daud, A. (1981). Sunan Abu Daud. Beirut: Dar al-Kutub al-'Ilmiyyat.

Dienes, C. T. (1972). Law, politics, and birth control: University of Illinois Press.

Durkheim, E. (1964). The Division of Labour in Society. New York: Free Press/Macmillan.

Fraire, A. E., Woda, B. A., Welsh, R. M., \& Kradin, R. L. (2014). Coronavirus. Viruses and the Lung: Infections and Non-Infectious Viral-Linked Lung Disorders, XIV.

Friedman, L. M. (2011). Sistem Hukum: Perspektif IImu Sosial, diterjemahkan oleh M. Khozim. Cet. Ke-4. Bandung: Nusa Media, 110.

Grad, H. (1949). On the kinetic theory of rarefied gases. Communications on pure and applied mathematics, 2(4), 331-407.

Habermas, J. (1984). The Theory of Communicative Action (trans. Thomas McArthy). Boston: Beacon Press.

Hadzami, S. I. (1986). Taudih al-Adillah, VII, 75-77.

Huang, C., Wang, Y., Li, X., Ren, L., Zhao, J., Hu, Y., . . . Gu, X. (2020). Clinical features of patients infected with 2019 novel coronavirus in Wuhan, China. The Lancet, 395(10223), 497-506.

Ibn 'Abd Al-Bar. (1387 H). Al-Tamhid li-ma fi al-Muwatta'min al-Ma 'ani wa al-Asanid. Maroko Wizarah al-Awqaf wa al-Syu 'un al-Islamiyyah.

Ibn Abi Syaybah, A. B. A. b. M. (2004). Al-Musannaf li Ibn Abi Syaybah. Al-Riyad: Maktabah al-Rusyd al-Nasyirun.

Ibn al-Munzir, A. B. M. b. I. (2010). Al-Awsat min al-Sunan wa al-ljma 'wa al-Ikhtilaf. al-Riyad: Dar alFalah.

Ibn Rushd. (n.d). Bidayah al-Mujtahid wa Nihayah al-Muqtasid. Indonesia: Daar al-Kutub alArabiyyah. 
INTERNATIONAL JOURNAL OF ACADEMIC RESEARCH IN BUSINESS AND SOCIAL SCIENCES

Vol. 10, No. 11, 2020, E-ISSN: 2222-6990 @ 2020 HRMARS

Kamil, U. A. (1999). Al-Rukhsah Al-Shar'iyyah Fi Al-Usul wa Al-Qawa'id Al-Fiqhiyyah. Beirut: Dar Ibn Hazm.

Kirk, J., Miller, M. L., \& Miller, M. L. (1986). Reliability and validity in qualitative research (Vol. 1): Sage.

Lee, S. A., Jobe, M. C., \& Mathis, A. A. (2020). Mental Health Characteristics associated with Dysfunctional Coronavirus Anxiety. Psychological Medicine, 1-5. doi:10.1017/S003329172000121X

Muslim, I. (1992). Shahih Muslim. Beirut: Darul Fikr, V.

Organization, W. H. (2020). Coronavirus disease 2019 (COVID-19): situation report, 67.

Rezaei, N. (2020). COVID-19 affects Healthy Pediatricians more than Pediatric Patients. Infection Control \& Hospital Epidemiology, 1-3. doi:10.1017/ice.2020.139

Shultz, J. M., Perlin, A., Saltzman, R. G., Espinel, Z., \& Galea, S. (2020). Pandemic March: COVID-19's first wave circumnavigates the globe. Disaster Medicine and Public Health Preparedness, 113. doi:10.1017/dmp.2020.103

Zakaria al-Anshari, A. (2003). Asna al-Mathalib. Dar al-Fikr, 2, 479.

Zhou, P., Yang, X. L., Wang, X. G., Hu, B., Zhang, L., Zhang, W., . . . Shi, Z. L. (2020). A pneumonia outbreak associated with a new coronavirus of probable bat origin. Nature, 579(7798), 270273. doi:10.1038/s41586-020-2012-7 